\title{
PENGARUH KUALITAS PRODUK DAN HARGA TERHADAP KEPUTUSAN PEMBELIAN PRODUK KERAJINAN KULIT PADA INDUSTRI KERAJINAN KULIT "FIGHA" MAGETAN
}

\author{
Dewi Susanti \\ Satrijo Budi Wibowo \\ Juli Murwani \\ Pendidikan Akuntansi IKIP PGRI MADIUN
}

\begin{abstract}
This study aims to determine whether there is any influence product quality and price either simultaneously or partially on product purchasing decisions leather on leather industry Figha Magetan. The method used in this study is a quantitative descriptive correlational method. Techniques of data collection using questionnaires in quantitative. The results showed that the quality of the product and the price effect on the purchasing decisions of handicraft products in leather industry Figha Magetan. However, the price variable is more influential on purchase decisions leather products on leather industries Figha Magetan.
\end{abstract}

Keyword: product quality, price, purchasing decision

\begin{abstract}
ABSTRAK
Penelitian ini bertujuan untuk mengetahui ada atau tidaknya pengaruh kualitas produk dan harga baik secara simultan atau secara parsial terhadap keputusan pembelian produk kerajinan kulit pada industri kerajinan kulit Figha Magetan. Metode yang digunakan dalam penelitian ini adalah metode deskriptif kuantitatif. Teknik pengumpulan data menggunakan kuesioner yang dikuantitatifkan. Hasil penelitiaan menunjukan bahwa kualitas produk dan harga berpengaruh terhadap keputusan pembeliaan produk kerajinan pada industri kerajinan kulit Figha Magetan. Namun variabel harga lebih berpengaruh terhadap keputusan pembelian produk kerajinan kulit pada indutri kerajinan kulit Figha Magetan.
\end{abstract}

Kata Kunci : Kualitas Produk, Harga, Keputusan Pembelian

\section{PENDAHULUAN}

Tuntutan dunia usaha yang semakin kompleks mengaharuskan sebuah industri kecil untuk mampu bersaing di dunia usaha, sehingga diharapkan dapat bertahan dan menguasai pangsa pasar. Penguasaan pangsa pasar tersebut tentunya harus diawali dengan penetapan strategi pemasaran yang tepat. Kegiatan pemasaran yang dilakukan selain berorientasi pada laba, tentunya juga diharapkan dapat menarik minat konsumen untuk melakukan pembelian. Menurut Gunawan Adisaputro, (2010: 18) "Konsumen yang sama seringkali tidak hanya dilayani oleh satu perusahaan tetapi oleh beberapa perusahaan yang saling bersaing satu sama lain." Strategi yang jelas dan mempunyai keunikan tertentu yang berbeda dengan strategi perusahaan lain diperluka untuk memenangkan persaingan tersebut. Dengan teridentifikasinya motif pembelian dari seorang konsumen, sebuah perusahaan akan dapat menetapkan strategi yang tepat untuk 
pengembangan usahanya. Semakin pesatnya dunia persaingan juga mengharuskan sebuah perusahaan untuk terus memantau perkembangan terhadap perilaku konsumennya, karena konsumen sebagai individu dalam memilih suatu jenis produk yang diinginkannya dan hal tersebut dipengaruhi oleh banyak faktor, dimana faktor-faktor tersebut berbeda antara satu dengan yang lain. Perbedaan ini dipengaruhi oleh faktor individu itu sendiri dan juga oleh faktor lingkungan yang mempengaruhinya. Perbedaan inilah yang mempengaruhi minat dan perilaku konsumen didalam mengambil keputusan pemilihan terhadap produk yang dinginkan.

Industri kerajinan kulit di kota Magetan khusunya Industri kerajinan kulit yang dipusatkan di jalan Sawo kelurahan Selosari Magetan sekitar $1 \mathrm{~km}$ arah barat kota Magetan. Hasil industri dengan bermacam-macam jenis produk antara lain sepatu, sandal dengan berbagai model, tas, dompet, ikat pinggang, serta bermacam-macam souvenir lainnya. Industri kerajinan kulit yang menjual produkproduk dari kulit di jalan Sawo ini sangatlah banyak dan semuanya mengaharapakan konsumen yang datang melirik produk mereka dan melakukan pembeliaan atas produk yang ditawarkan. Salah satu Industri kerajinan kulit yang ada di jalan sawo adalah "Figha". Industri ini mempunyai letak yang sangat strategis yakni di jalan Sawo lokasinya tepat pada jalan masuk di kawasan industri jalan Sawo no 86.

\section{TINJAUAN PUSTAKA}

Dalam melakukan keputusan pembelian seorang konsumen tentunya akan melihat beberapa aspek yang terkandung pada produk tersebut baik dari segi kualitas maupun harganya. Hingga pada akhirnya konsumen memutuskan untuk membeli produk yang ada, dan untuk menghindari terjadinya ketidakpuasan pascapembelian, seorang konsumen melakukan beberapa pertimbangan dengan beberapa tahap sebelum ia memutuskan untuk membeli produk. Produk yang berkualitas dengan harga yang terjangkau akan menjadi pertimbangan kosumen dalam melakukan keputusan pembelian. Banyaknya produk dengan berbagai karakteristik yang berbeda mengharuskan konsumen melakukan serangkaian pertimbangan keputusan pembelian.

Hal tersebut diperkuat oleh pendapat (Basu Swasatha, 2008: 121) yaitu "jika dianggap bahwa keputusan pembelian yang diambil oleh konsumen adalah membeli, maka pembeli akan menjumpai serangkaian keputusan menyangkut jenis produk, merek, penjual, kuantitas, waktu pembelian, dan cara pembayarannya". Dalam kaitan ini konsumen juga akan mendapat pengaruh lain dalam melakukan keputusan pembelian. Morissan, (2010: 111) menjelaskan "keinginan membeli secara umum didasarkan pada upaya mencocokan motif pembelian dengan atribut atau karakteristik merek yang tengah dipertimbangkan dengan melibatkan aspek psikologi, seperti motivasi, persepsi, sikap dan integrasi". Banyaknya hal yang mempengaruhi seseorang dalam melakukan keputusan pembelian, mengharuskan ia melakukan pengidentifikasian atas tawaran produk dengan berbagai macam merek, dengan harapan keputusan pembelian yang dilakukan dapat memberi kepuasan yang maksimal atas produk yang sudah dibeli.

Sedangkan menurut Thamrin Abudllah dan Francis Tantri (2012: 132) yang menjelaskan bahwa "keputusan pembelian merupakan tahap evaluasi konsumen 
membentuk preferensi antara merek-merek dalam kelompok pilihan". Pilihan dalam keputusan pembelian ini berkaitan dengan resiko yang akan dihadapi oleh konsumen ketika ia akan memutuskan membeli sebuah produk, sehingga konsumen perlu melakukan sebuah pertimbangan. Pertimbangan pembelian yang dilakukan konsumen ini dijelaskan oleh (Paul dan Loise, 2005, terjemahan Ardi Gunawan, 2006: 60) yaitu:

"mengenai (1) keuangan (mampukah saya membelinya?, dan apakah saya mendapatkan nilai dari uang yang saya miliki?), (2) performa (apakah produk tersebut akan bermanfaat?), (3) fisik (apakah produk tersebut mendatangkan bahaya bagi saya?), (4) psikologi (apakah produk tersebut sesuai dengan citra pribadi saya?), (5) sosial (apakah produk tersebut dapat diterima orang lain).

Teori yang mendasari dalam penelitian ini adalah teori dari (Basu Swasatha, 2008: 121) yaitu "jika dianggap bahwa keputusan pembelian yang diambil oleh konsumen adalah membeli, maka pembeli akan menjumpai serangkaian keputusan menyangkut jenis produk, merek, penjual, kuantitas, waktu pembelian, dan cara pembayarannya. Dalam teori tersebut peneliti menggaris bawahi pada jenis produk dan cara pembayaranya. Pada saat konsumen memutuskan untuk membeli, maka ia mempertimbangkan mengenai jenis produk, yang dalam kaitan ini menyangkut pula pada kualitas yang ada pada produk tersebut dan cara pembayaran yang tentunya berkaitan pula dengan harga produk yang ada.

Dalam penelitian ini variabel selanjutnya yang akan diungkap adalah kualitas produk. Penciptaan sebuah produk yang berkualitas sangatlah penting untuk diterapkan di perusahaan, kualitas produk menjadi daya tarik tersendiri dan pertimbangan bagi konsumen untuk melakukan keputusan pembelian, karena kualitas produk itu sendiri merupakan salah satu faktor utama dari sebuah produk itu yang dapat menunjukan sebuah gambaran dari produk tersebut saat dipakai, daya tahan dari produk tersebut dibandingkan dengan produk lainnya, sehingga dari semuanya itu dapat menunjukan sebuah kualitas produk yang baik. Kualitas produk selalu berhubungan dengan persepektif kualitas dan dimensi kualitas itu sendiri.

Hal tersebut diperkuat oleh pendapat Sofjan Assauri, (2011: 212) yang menyebutkan bahwa "kualitas produk menunjukan ukuran tahan lamanya produk itu, dapat dipercayainya produk tersebut, ketepatan (precision) produk, mudah mengoprasikan dan memeliharanya serta atribut lain yang dinilai”. Dengan terciptanya sebuah kualitas yang baik pada sebuah produk ini akan dapat menunjukan keunggulan dari produk tersebut. Hal tersebut sejalan dengan (Kotler dan Nancy, 2007, terjemahan M. Taufik Amir, 2007: 53) yang menyebutkan bahwa "kualitas produk merupakan segala sesuatu yang mengacu pada kinerja produk tersebut". Kinerja dari sebuah produk akan terlihat maksimal dan baik, bila dalam proses pembuatnya menggunakan bahan-bahan yang berkualitas pula. Crosby (dalam Nasution, 2004: 41) menambahkan bahwa "kualitas adalah conformance to requirment, yaitu sesuai dengan yang disyaratkan atau distandartkan". Suatu produk memiliki kualitas apabila sesuai dengan standart kualitas yang telah ditentukan. Standart kualitas ini meliputi bahan baku, proses produksi, dan produk jadi”.

Teori kualitas produk yang mendukung dalam penelitian ini berdasarkan pada pendapat Sofjan Assauri, (2010: 212) yang menyebutkan bahwa "kualitas produk menunjukan ukuran tahan lamanya produk itu, dapat dipercayainya 
produk tersebut, ketepatan (precision) produk, mudah mengoprasikan dan memeliharanya serta atribut lain yang dinilai". Dari segi pandangan pemasaran, kualitas diukur dalam ukuran persepsi pembeli tentang mutu/kualitas produk tersebut. "Kebanyakan produk disediakan atau diadakan mulanya berawal pada suatu diantara empat tingkat kualitas, yaitu kualitas rendah, kualitas rata-rata (sedang), kualitas baik (tinggi), dan kualitas sangat baik" (Sofjan Assauri, 2010: 212).

Adanya penilaian bahwa dengan harga yang tinggi maka akan diperoleh barang atau produk yang berkualiatas, ini seolah sudah melekat dalam benak konsumen, namun bisa saja paradigma tersebut berubah seiring adanya penetapan harga yang sesuai, yang mencerminkan dari kualitas produk yang ada. Para konsumen akan selalu membandingkan harga pada produk yang sejenis sebelum ia melakukan keputusan pembelian. Menurut Sofyan Asauri (2010: 224) "harga mempengaruhi kemampuan bersaing perusahaan dan kemampuan perusahaan mempengaruhi konsumen". Harga bisa menjadi patokan yang penting dalam sebuah produk yang telah diluncurkan.

Pendapat tersebut diperjelas oleh Gunawan Adisaputra (2010: 209) "harga jual produk adalah salah satu elemen dalam bauran pemasaran yang menghasilkan revenue penjualan, sedangkan elemen lain dari bauran itu menghasilkan biayabiaya". Tidak sedikit perusahaan yang turun nilai penjualannya karena kurang tepatnya dalam menentukan kebijakan harga. Kebijakan harga yang dibuat perusahaan hendaknya bisa bersifat konsisten sehingga konsumen tidak mudah berpaling pada produk yang lain.

Dalam penelitian ini teori yang mendasari tentang harga adalah teori dari Sofyan Assauri (2010: 224) "harga mempengaruhi kemampuan bersaing perusahaan dan kemampuan perusahaan mempengaruhi konsumen”. Harga yang dibentuk oleh suatu perusahaan dapat menjadi pencerminan atas kualitas produk yang dihasilkan. Dengan adanya sebuah penetapan harga terhadap produk yang dihasilkan diharapkan itu dapat menjadi sebuah pertimbangan sendiri bagi para konsumen yang datang untuk melakukan pembeliaan pada produk kerajinan kulit. Dalam penetapan kebijakan harga tentunya perusahaan juga harus memperhatikan pada setiap jenis produk yang dihasilakan, sehingga akan ada difrensiasi (perbedaan) harga untuk setiap jenis produk dengan kualitas yang berbeda pula.

\section{HIPOTESIS PENELITIAN}

Adapun hipotesis dalam penelitian ini adalah:

H1 : Terdapat Pengaruh Kualitas Produk dan Harga Terhadap Keputusan Pembelian Produk Kerajinan Kulit Pada Industri Kerajinan Kulit "FIGHA" MAGETAN

\section{METODOLOGI PENELITIAN \\ Desain Penelitian}

Desain penelitian atau rancangan penelitian adalah semua proses yang diperlukan dalam perencanaan dan pelaksanaan penelitian. Variabel dalam penelitian ini adalah Variabel bebas $(\mathrm{X})$ yaitu $\mathrm{X}_{1}=$ kualitas produk, $\mathrm{X}_{2}=$ Harga. Variabel terikat (Y) dalam penelitian ini adalah keputusan pembelian. Untuk lebih jelasnya dapat dilihat gambar dibawah ini: 


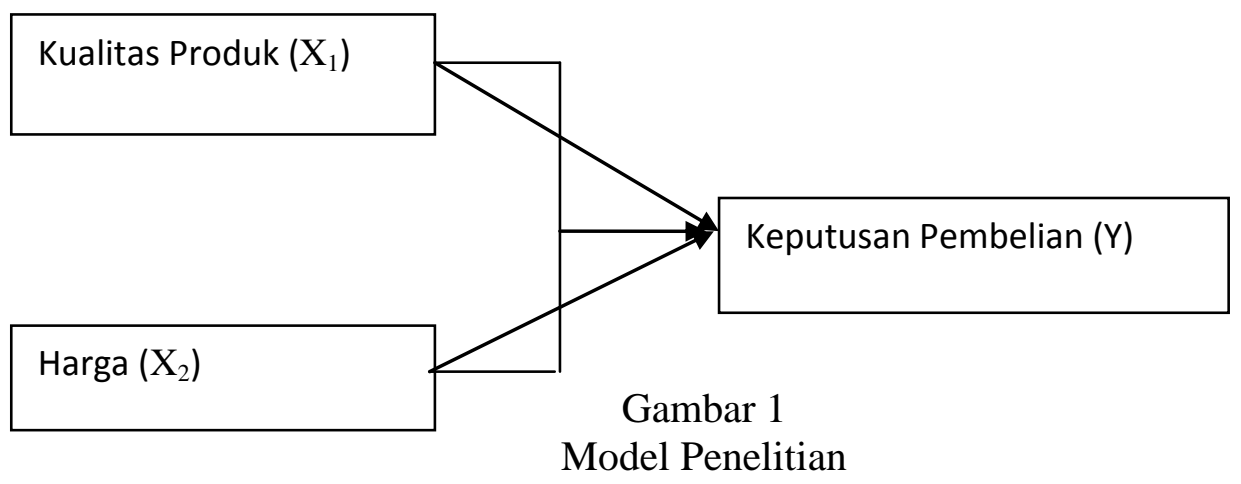

\section{Populasi, Sampel, Teknik Pengambilan Sampel}

Populasi dalam penelitian ini adalah seluruh konsumen yang pernah melakukan pembelian pada industri kerajinan kulit Figha selama tiga tahun terakhir dari tahun 2010-2012 yaitu berjumlah 1.358 konsumen. Dari perhitungan dapat ditentukan besarnya sampel dalam penelitian ini sebanyak 93 orang responden. Teknik pengambilan sampel yang digunakan dalam penelitian ini adalah dengan teknik non probabilitas sampling dengan model sampling aksidental.

\section{Teknik Analisis Data}

Metode analisis data merupakan cara yang utama digunakan untuk mengolah data yang terkumpul sehingga dapat menghasilkan suatu kesimpulan yang dapat dipertanggungjawabkan. Dalam penelitian ini menggunakan Analisis Regresi Linnier berganda. Dilakukan pula dengan Uji SPSS (Statistical Product dan Service Solutions) for windows versi 17.0 dengan langkah-langkah sebagai berikut :

\section{Uji Instrumen}

a. Uji Validitas

Validitas adalah suatu ukuran yang menunjukkan tingkat-tingkat kevalidan atau kesahihan suatu instrumen. "Cara menentukan apakah suatu item valid atau tidak dapat dilakukan dengan membandingkan nilai $r$ hitung (nilai person correlation) dengan $r$ tabel (didapat dari $r$ tabel). Nilai $r$ tabel dicari menggunakan tingkat signifikansi 0,05 dengan uji 2 sisi” (Duwi Priyatno, 2012: 120).

b. Uji Reliabilitas

Uji reliabilitas digunakan untuk mengetahui keajegan atau konsistensi alat ukur yang biasa menggunakan kuesioner (maksudnya apakah alat ukur tersebut akan mendapatkan pengukuran yang tetap konsisten jika pengukuran diulang kembali. Metode yang sering digunakan dalam penelitian untuk mengukur skala rentangan (seperti skala likert 1-5) adalah Cronbach Alpha dengan menggunakan batasan 0,6, dapat ditentukan apakah instrumen reliabel atau tidak" Menurut Sekaran (dalam Duwi Priyatno, 2012: 120) "reliabilitas kurang dari 0,6 adalah kurang baik, sedangkan 0,7 dapat diterima, dan di atas 0,8 adalah baik.

\section{Uji Asumsi Klasik}

Ada empat uji asumsi klasik yang digunakan dalam analisis ini yaitu: 
a. Uji Normalitas

"Uji normalitas untuk mengetahui apakah variabel dependen, independen atau keduanya berdistribusi normal, mendekati normal atau tidak" (Husein Umar, 2011: 181). "Normalitas suatu data penting karena dengan data yang berdistribusi normal, maka data tersebut dianggap dapat mewakili suatu populasi" (Duwi Priyatno, 2012: 33).

b. Uji Autokorelasi

"Uji autokorelasi dilakukan untuk mengetahui apakah dalam sebuah model regresi linier terdapat hubungan yang kuat baik positif maupun negatif antar data yang ada pada variabel-variabel peneitian".

c. Uji Multikolinieritas

"Uji multikolinieritas untuk mengetahui apakah pada model regresi ditemukan adanya korelasi antar variabel independen. Jika terjadi korelasi, terdapat masalah multikolinieritas yang harus diatasi" (Husein Umar, 2011: 177). Duwi Priyatno, (2012: 93) menambahkan bahwa "Model regresi yang baik adalah yang terbebas dari multikolinearitas".

d. Uji Heteroskedastisitas

"Uji heteroskedastisidas dilakukan untuk mengetahui apakah dalam sebuah model regresi terjadi ketidaksamaan varians dari residual suatu pengamatan ke pengamatan lain". menurut Duwi Priyatno (2012: 93) "regresi yang baik seharusnya tidak terjadi heteroskedastisitas".

\section{Analisis Regresi linier Ganda}

Duwi Priyatno, (2012: 80) menjelaskan bahwa "Analisis regresi liner berganda adalah hubungan secara linier antara dua atau lebih variabel independen dengan satu variabel dependen yang digunakan untuk memprediksi atau meramalkan suatu nilai variabel dependen berdasrkan variabel independen". Berikut adalah persamaan regresi liner berganda dengan dua variabel :

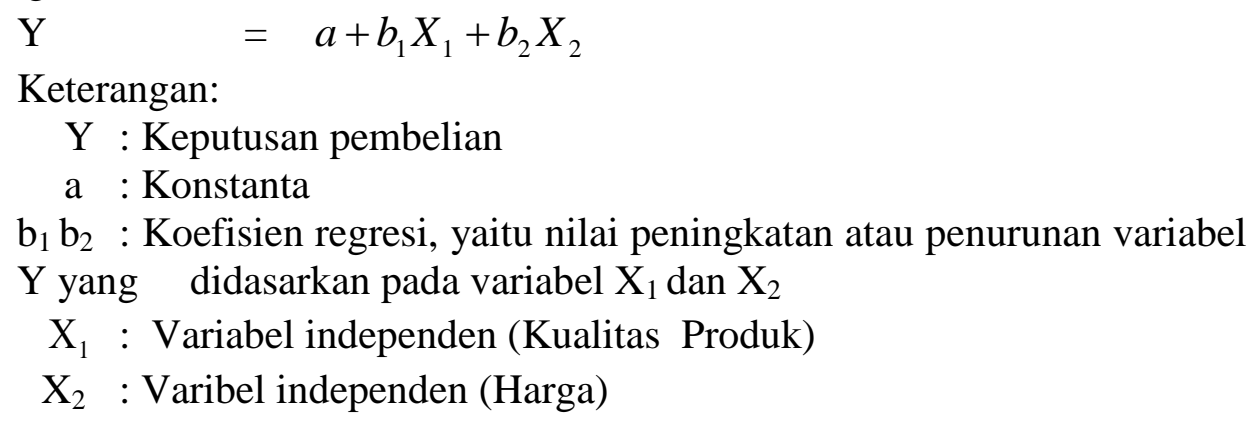

\section{Uji Hipotesis}

a. Uji Parsial (Uji t)

"Uji t untuk mengetahui pengaruh varibel independen secara parsial terhadap variabel depenen, apakah pengaruhnya signifikan atau tidak" (Duwi Priyatno, 2009: 50)

b. Uji F

"Uji F digunakan untuk mengetahui pengaruh secara bersama-sama antara variabel independen terhadap variabel dependen"' (Duwi Priyatno, 2012: 89). 


\section{HASIL PENELITIAN}

\section{Uji Assumsi Klasik}

1. Uji Normalitas

Dalam pengujian ini digunakan metode Normal Probability Plots. Normal Probability Plots berbentuk grafik yang digunakan untuk mengetahui apakah dalam sebuah model regresi, nilai regresi residual terdistribusi dengan normal. Hasil dari uji normalitas dengan SPSS for windows versi 17.0 sebagai berikut:

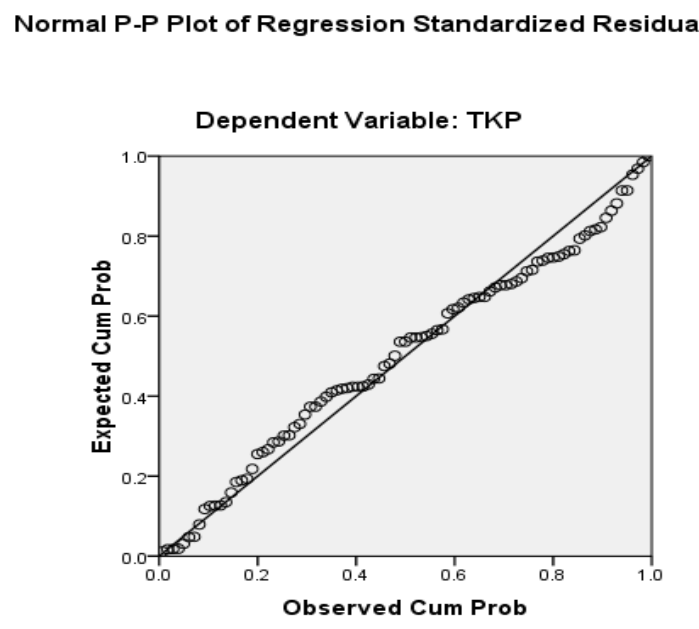

Gambar 2

Hasil Uji Normalitas

Sumber: data penelitian yang telah dioalah dengan SPSS

Berdasarkan gambar diatas terlihat titik-titik menyebar di sekitar garis diagonal, serta penyebaranya mengikuti arah garis diagonal. Hal ini dapat disimpulkan bahwa model regresi layak dipakai karena memenuhi asusmsi normalitas.

2. Uji Autokorelasi

Hasil uji auotokorelasi dapat dilihat pada tabel dibawah ini:

Tabel 5 Uji Autokorelasi dengan distribusi Durbin-Watson

\begin{tabular}{|c|c|c|c|c|c|}
\hline \multicolumn{6}{|c|}{ Model Summary } \\
\hline $\begin{array}{l}\text { Mode } \\
1\end{array}$ & $\mathbf{R}$ & $\begin{array}{c}\mathbf{R} \\
\text { Square }\end{array}$ & $\begin{array}{c}\text { Adjusted R } \\
\text { Square }\end{array}$ & $\begin{array}{c}\text { Std. Error } \\
\text { of the } \\
\text { Estimate }\end{array}$ & $\begin{array}{l}\text { Durbin- } \\
\text { Watson }\end{array}$ \\
\hline 1 & $.546^{\mathrm{a}}$ & .298 & .283 & 3.208 & 2.303 \\
\hline
\end{tabular}

Sumber : Data Penelitian Yang Telah Diolah dengan SPSS

Dari hasil analisis diatas dapat diketahui nilai DW sebesar 2,303 sedangkan nilai $\mathrm{dU}$ dan dL untuk jumlah data 93 pada taraf signifikan 5\% dan $\mathrm{k}=2$ adalah 1,6188 dan 1,7066. Model regrsi linier berganda dikatakan tidak ada autokorelasi apabila DW terletak antara dU dan 4-dU. nilai DW berdasarkan tabel di atas diperoleh sebesar 2,303; nilai tersebut terletak diantara dU (1,6188) dan 4-dU (4-1,7066); 
maka dapat dismpulkan bahwa model regresi linier berganda tidak terdapat autokorelasi.

3. Uji Multikolinearitas

Berikut hasil uji multikolinearitas

Tabel 6 Uji Multikolinearitas dengan distribusi Durbin-Watson

\begin{tabular}{|c|c|c|c|c|c|c|c|c|}
\hline \multirow{2}{*}{\multicolumn{2}{|c|}{ Model }} & \multicolumn{2}{|c|}{$\begin{array}{l}\text { Unstandardized } \\
\text { Coefficients }\end{array}$} & \multirow{2}{*}{\begin{tabular}{|c}
$\begin{array}{c}\text { Standardize } \\
\mathrm{d} \\
\text { Coefficients }\end{array}$ \\
Beta
\end{tabular}} & \multirow{2}{*}{$\mathrm{T}$} & \multirow{2}{*}{ Sig. } & \multicolumn{2}{|c|}{$\begin{array}{c}\text { Collinearity } \\
\text { Statistics }\end{array}$} \\
\hline & & B & $\begin{array}{l}\text { Std. } \\
\text { Error }\end{array}$ & & & & Tolerance & VIF \\
\hline & $\begin{array}{c}\text { (Consta } \\
\text { nt })\end{array}$ & 12.461 & 2.584 & & 4.822 & .000 & & \\
\hline & TK & .210 & .082 & .239 & 2.551 & .012 & .885 & 1.129 \\
\hline & $\mathrm{TH}$ & .373 & .084 & .416 & 4.437 & .000 & .885 & 1.129 \\
\hline
\end{tabular}

a. Dependent Variable: TKP

Sumber : Data Penelitian Yang Telah Diolah dengan SPSS

Dari hasil analisis diatas dapat diketahui nilai dari VIF untuk variabel $\mathrm{X}_{1}$ (TK) dan $\mathrm{X}_{2}(\mathrm{TH})$ adalah 1,129 sehingga nilai tersebut kurang dari 10. Jadi dapat disimpulkan bahwa model regresi tersebut tidak terdapat indikasi multikolinieritas

4. Uji Heteroskedastisitas

Model regresi yang baik adalah yang heteroskedastisitas pengambilan keputusannya yaitu:

1) Jika ada pola tertentu, seperti titik-titik yang ada membentuk suatu pola tertentu yang teratur (bergelombang, melebar, kemudian menyempit), maka terjadi heteroskedastisitas.

2) Jika tidak ada pola yang jelas, seperti titik-titik menyebar di atas dan dibawah angka 0 pada sumbu Y, maka tidak terjadi heteroskedastiditas. 
Scatterplot

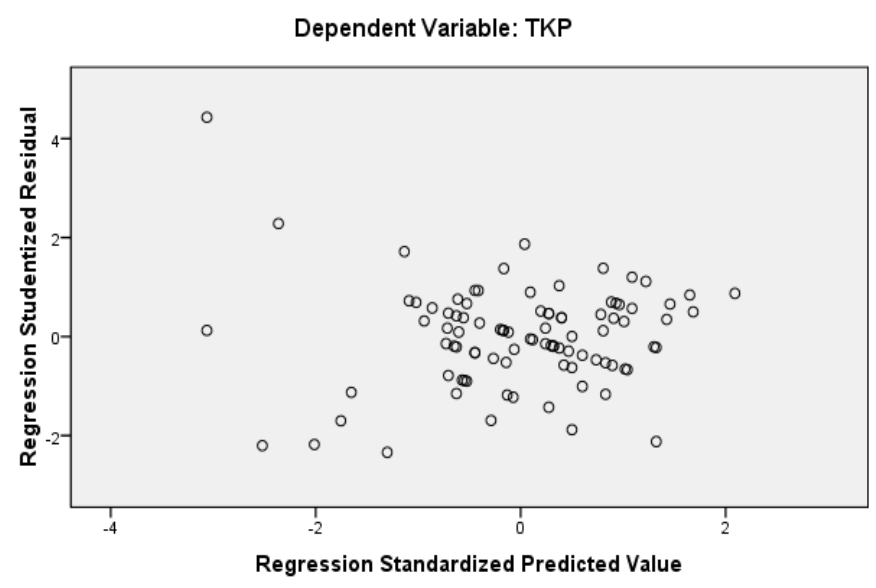

Gambar 3

Hasil Uji Heteroskedastisitas

Sumber : Data Penelitian Yang Telah Diolah dengan SPSS

Berdasarkan grafik diatas dapat terlihat bahwa distribusi data tidak teratur dan tidak membentuk pola tertentu, serta tersebar diatas dan dibawah angka 0 pada sumbu Y, sehingga dapat dismpulkan bahwa pada model regresi ini tidak terjadi masalah heteroskedastisitas.

\section{Analisis Regresi Berganda}

Hasil pengeolahan data dengan menggunakan program SPSS for windows versi 17.0 dan didapatkan persamaan regresi :

Tabel 7 Hasil Uji Regresi Linier Berganda

\begin{tabular}{|c|c|c|c|c|c|}
\hline \multirow[t]{2}{*}{ Model } & \multicolumn{2}{|c|}{$\begin{array}{c}\text { Unstandartixed } \\
\text { Coefficients }\end{array}$} & $\begin{array}{c}\text { Standardized } \\
\text { Coefficient }\end{array}$ & $\mathrm{T}$ & Sig. \\
\hline & $\mathrm{B}$ & Std.Error & Beta & & \\
\hline $\begin{array}{c}1 \\
\text { (Constant) } \\
\end{array}$ & 12.461 & & & 4.822 & .000 \\
\hline TK & .210 & .239 & .239 & 2.551 & .012 \\
\hline $\mathrm{TH}$ & .373 & .416 & .416 & 4.437 & .000 \\
\hline
\end{tabular}

Dependent Variabel : TKP

Sumber : data penelitian yang telah diolah dengan SPSS

Berdasarkan hipotesis yang ada diperoleh temuan sebagai berikut:

1. Temuan hasil penelitiaan menunjukan bahwa berdasarkan hasil penafsiran analisis data yang disesuaikan dengan item pernyataan dalam koesioner dan pengujian hipotesis telah membuktikan terdapat pengaruh kualitas produk terhadap keputusan pembelian. Melalui hasil perhitungan diperoleh $t$ hitung 2,551 sedangkan $t$ tabel sebesar 1,987. Itu artinya thitung lebih besar dari $t$ tabel. Dengan demikian Ho ditolak dan Ha diterima, pengujian ini secara 
parsial membuktikan bahwa kualitas produk berpengaruh terhadap keputusan pembelian. Dimana kualitas produk ini mempunyai daya tarik tersendiri yang dapat memikat konsumen dalam melakukan keputusan pembelian. Sebaliknya kualitas produk yang rendah akan mengurangi minat konsumen untuk melakukan pembelian atas suatu produk.

2. Temuan Hasil Penelitian tentang Harga $\left(\mathrm{X}_{2}\right)$ Berpanguh Positif terhadap Keputusan Pembelian (Y).

Temuan hasil penelitian ini menjelaskan bahwa berdasarkan hasil penafsiran analisis data yang disesuaikan dengan item pernyataan dalam koesioner dan pengujian hipotesis telah membuktikan terdapat pengaruh variabel harga terhadap keputusan pembelian. Melalui hasil perhitungan diperoleh thitung 4,437 sedangkan t tabel sebesar 1,987. Itu artinya t hitung lebih besar dari t tabel. Dengan demikian Ho ditolak dan Ha diterima, pengujian ini secara parsial membuktikan bahwa harga berpengaruh terhadap keputusan pembelian.

Hal ini sesuai dengan pendapat Thamrin Abdullah dan Francis Tantri (2012: 189) yang menyatakan bahwa "diskon memberikan rangsangan kepada pelanggan untuk memesan dari seorang penjual tertentu dari pada membeli dari banyak sumber". Kondisi tersebut terlihat dalam strategi yang diciptakan oleh industri kerajinan kulit Figha yang menawarkan harga terjangkau dengan diskon pada setiap produknya diiringi dengan adanya pelayanan untuk pemesan produk bagi konsumen, sehingga tidak heran bila harga dalam penelitian ini memiliki pengaruh yang lebih besar dibandingkan dengan kualitas produk terhadap keputusan pembelian.

Hasil temuan dalam penelitian ini sesuai dengan kajian teori yang memuat adanya pengaruh harga terhadap keputusan pembelian sebagaimana yang dikemukakan oleh Gunawan Adisaputro, (2010: 209) menyatakan bahwa "harga jual produk adalah salah satu elemen dalam bauran pemasaran yang menghasilkan revenue penjualan, sedangkan elemen lain dari bauran itu mengasilkan biaya-biaya". Dengan begitu akan terlihat bahwa dengan meningkatnya hasil penjualan, maka itu akan menunjukkan bahwa pembelian akan suatu produk tersebut meningkat pula.

3. Temuan Hasil Penelitian tentang Kualitas Produk $\left(\mathrm{X}_{1}\right)$ dan Harga $\left(\mathrm{X}_{2}\right)$, Berpengaruh Positif terhadap Keputusan Pembelian (Y)

Temuan hasil penelitian berdasarkan hasil penafsiran diketahui bahwa kedua variabel $\left(\mathrm{X}_{1}\right.$ dan $\left.\mathrm{X}_{2}\right)$ secara simultan atau bersama-sama berpengaruh terhadap variabel dependen Keputusan Pembelian (Y), keduanya merupakan faktor paling penting dalam peningkatan penjualan produk kerajinan kulit.

Analisis besarnya pengaruh kualitas produk dan harga terhadap keputusan pembeian diperoleh $\mathrm{F}$ hitung sebesar 19,119 dengan tingkat signifikansi 0,000 dan $\mathrm{F}$ tabel diperoleh sebesar 3,097698. maka, model regresi ini bisa dipakai untuk memprediksi variabel dependen (keputusan pembelian). Hal ini menunjukan terdapat pengaruh simultan yang signifikan antara kualitas produk dan harga terhadap keputusan pembelian produk kerajinan kulit pada industri kerajinan kulit Figha Magetan.

Bentuk pengaruh variabel kualitas produk dan harga terhadap keputusan pembelian adalah pegaruh positif yang ditunjukan dengan nilai koefisiensi regresi yang bertanda positif. Dengan demikian penetapan standart kualitas 
produk dan harga dengan baik dan maksimal pada setiap produk kerajinan kulit yang ada, maka akan memberikan pengaruh yang positif terhadap keputusan pembelian di industri kerajinan kulit Figha.

\section{KESIMPULAN DAN SARAN \\ Kesimpulan}

Berdasarkan hasil penelitian tentang pengaruh kualitas produk dan harga terhadap keputusan pembelian produk kerajinan kulit pada 93 responden yang merupakan konsumen Industri Kerajinan Kulit Figha, maka dapat ditarik kesimpulan sebagai berikut:

1. Berdasarkan hasil analisis data dan pengujian hipotesis dalam penelitian ini dapat disimpulkan bahwa kualitas produk dan harga, secara bersama-sama berpengaruh terhadap keputusan pembelian. Kedua variabel tersebut mempunyai pengaruh yang besar terhadap keputusan pembelian. Akan tetapi variabel harga mempunyai pengaruh yang lebih dominan dibandingkan dengan variabel keputusan pembelian. Dengan demikian, konsumen lebih memperhatikan harga yang ditawarkan oleh industri kerajinan kulit Figha dari pada variabel kualitas produk.

2. Kelebihan dari variabel kualitas produk dan harga terhadap keputusan pembelian adalah sebagai berikut :

a. Harga yang ditetapkan pada produk kerajinan kulit Figha mampu menarik minat beli konsumen. Hal ini dikarenakan industri kerajinan kulit Figha menawarkan harga yang sepadan dengan nilai dan kualitas produknya, selain itu industri kerajinan kulit Figha juga memberikan diskon untuk pembelian setiap produknya, sehingga harga yang ditawarkan bisa lebih rendah dibandingkan dengan produk lain. Akan tetapi dengan penetapan harga yang rendah, perusahaan tidak dapat memperoleh laba yang tinggi.

b. Semua produk yang dihasilkan oleh industri kerajinan kulit Figha memiliki kualitas sedang, sehingga perusahaan dapat menekan biaya produksi yang dikeluarkan. Dengan penekanan biaya produksi, maka akan mampu menciptakan harga jual produk yang tidak terlalu tinggi, sehingga minat beli konsumen dalam melakukan keputusan pembelian akan meningkat.

3. Kelemahan dari variabel kualitas produk dan harga terhadap keputusan pembelian adalah sebagai berikut :

a. Perusahaan cenderung menetapkan harga yang rendah agar dapat dijangkau oleh semua kalangan konsumen. Sebab Penetapan harga yang tinggi akan mempengaruhi minat konsumen dalam melakukan keputusan pembelian, sehingga hal tersebut akan mengakibatkan penurunan volume penjualan.

b. Dengan penekanan biaya produksi, maka kualitas produk yang dihasilkan tidak terlalu tinggi, sehingga minat beli konsumen akan menurun dan konsumen akan lebih selektif dalam memilih produk yang dibelinya.

\section{Saran}

Berdasarkan hasil penelitian dan simpulan yang dikemukakan diatas, penulis memberikan saran sebagai berikut :

1. Dengan ketatnya persaingan yang ada industri kerajinan kulit Figha harus selalu memperhatikan strategi dalam penetapan harga, dimana penciptaan 
harga harus didasarkan dan selalu disesuaikan dengan kualitas, jenis, dan desain produk, sehingga konsumen tidak akan merasa dirugikan dengan harga yang telah dibayarkan untuk produk yang telah dibelinya dan ini akan lebih meningkatkan minat konsumen dalam melakukan keputusan pembelian. Hal ini tentunya akan lebih meningkatkan image dari industri kerajinan kulit Figha yang selalu memberikan harga yang sesuai dengan kualitas produknya.

2. Industri kerajinan kulit Figha sebaiknya harus lebih meningkatkan kualiatas produk yang dihasilkan, karena dengan peningkatan perbaikan kualitas yang lebih baik, maka akan lebih meningkatkan tingkat penjualan atas produk yang dihasilkan, perbaikan kualitas ini tentunya harus meliputi bahan baku, proses pembuatan dan produk jadi yang dihasilkan, sehingga diharapkan industri kerajinan kulit Figha mampu menghasilakn produk dengan kualitas yang tinggi dan memiliki produk uggulan yang dapat menjadi ciri khas dari produk Figha dan mampu bersaing di pasaran.

3. Dalam penelitian ini hanya terbatas pada dua variabel kualitas produk dan harga dalam mempengaruhi keputusan pembelian produk kerajinan kulit. Untuk penelitian selanjutnya diharapkan peneliti bisa menambah variabel yang dapat mempengaruhi dalam keputusan pembelian seperti kualitas pelayanan dan promosi atau variabel lain yang terkait, sehingga akan terlihat hasil yang lebih signifikan.

\section{DAFTAR PUSTAKA}

Basu Swastha. 2008. Manajemen Pemasaran Moderen. Yogyakarta: Liberty Offset

Duwi Priyatno. 2009. 5 jam belajar olah data dengan SPSS 17.Yogyakarta: ANDI

2012. Teknik Mudah dan Cepat Analisis Data Penelitian dengan SPSS dan Tanya Jawab Ujian Pendadaran. Yogyakarta: Gava Media.

Garvin dalam Zulian Yamit. 2004. Manajemen Kualitas Produk dan Jasa. Yogyakarta: Ekonisia.

Gunawan Adisaputro. 2010. Manjemen Peemasaran.Yogyakarta: Sekolah Tingi Ilmu Manajemen YKPN.

Husein Umar. 2011. Metode Penelitian Untuk skripsi dan Tesis Bisnis. Jakarta: Raja Grafindo Persada.

Kotler, Philip dan Keller, Kevin Lane. 2009. Manajemen Pemasaran. Terjemahan Bob Sabran. Jakarta: Erlangga.

Kotler, Philip dan Lee Nancy. 2007. Pemasaran di Sektor Publik. Terjemahan M. Taufik Amir. Jakarta: PT. INDEKS. 
Morissan. 2010. Periklanan Komunikasi Pemasaran Terpadu. Jakarta: Kencana Prenada Media Group.

Nasution. 2004. Maaejemen Jasa Terpadu. Bogor: GHALIA INDONESIA.

Paul N. Bloom \& Louise N. Boone. 2006. Strategi Pemasaran Produk 18 Langkah Membangun Jaringan Pemasaran Produk yang Kokoh. Terjemahan Ardi Gunawan. Jakarta: PT. Prestasi Pustakarya.

Riduwan dan Akdon. Rumus dan Data dalam Statistika. Bandung: Alfabeta.

Sofjan Assauri. 2011. Manajemen Pemasaran. Jakarta: Rajawali.

Suharsimi Arikunto. 2010. Prosedur Penelitian Suatu Pendekatan Praktek. Jakarta: PT Rineka Cipta.

Sugiyono. 2008. Metode Penelitian Kuantitatif, Kualitatif dan $R \& D$. Bandung: Alfabeta.

-2011. Metodologi Penelitian Pendidikan (Pendekatan Kuantitatif, Kualitatif, dan $R \& D$. Bandung: Alfabeta.

Thamrin Abudullah dan Francis Tantri. 2012. Manajemen Pemasaran. Jakarta: PT RajaGrafindo Persada. 